\title{
On the problem of bias in political argumentation: An investigation into discussions about political asylum in Germany and Austria
}

\author{
Manfred Kienpointner ${ }^{\mathrm{a}}$, Walther Kindt ${ }^{\mathrm{b}}$ \\ "Institut für Sprachwissenschaft, Un'versity of Innsbruck, Innrain 52, A-6020 Innsbruck, Austria \\ " Fakultät für Linguistik und Literaturnissenschaft, Universität Bielefeld, Postfach 100131, \\ D-33501 Bielefeld, Germany
}

Received March 1995; revised version May 1996

\begin{abstract}
This paper attempts to combine descriptive and normative approaches to the study of argumantation. Starting from the insights of ancient rhetoric and dialectic (Aristotle, Cicero), New Rhetoric (Perelman and Olbrechts-Tyteca), the Pragma-Dialectic framework (Van Eemeren and Grootendorst) and the theory of fallacies developed by Woods and Walton, bias is defined as a lack of appropriate balance and critical doubt relative to a specific kind of argumentative discourse. More particularly, two main kinds of bias are distinguishable: global and local bias. The former consists in a neglection of global dimensions of the issue in question; the latter results from an incoraplete and/or incorrect application of argument schemes. A sample of about 80 letters to the editor written 1991-1992, where the problem of political asylum in Austria and Germany is the central issue, is described and critically evaluated in relation to the argument schemes and strategies of verbalization which are used. Two specific letters are analyzed in some detail. Finally, some recommendations concerning the improvement of both the climate and the standards of political discussions are suggested (e.g. the widespread practice of 'semantic fights' with the aim of pushing through one's own use of political terms should be replaced by the use of (more) impartial terms).
\end{abstract}

\section{Introduction}

The use of empirical methods raken from linguistic discourse analysis increasingly proves fruitful for the study of argumentation. On the one hand, progress in the development of a theory of everyday argumentation is not possible without a detailed knowledge of the processes and structures of argumentation in natural language; on the other hand such knowledge is indispensable for well-founded analyses of argumentative discourse. Furthermore, the success of empirical research can be demonstrated through the possibility of practical application. The results of empirical studies can be used, for example, to identify problems in everyday instances of 
political argumentation and to suggest practical solutions. In our paper, we attempt to serve both descriptive and normative interests in the study of argumentation, much in the spirit of Van Eemeren et al. (1993), who study various types of argumentative discourse in less than ideal circumstances in order to enhance both the theory and the practice of argumentation. As empirical data, we have collected a sample of about 80 letters to the editor in German and Austrian journals and magazines of the years 1991-92. The central issue of these letters is the problem of political asylum. The sources of all passages quoted below can be found in the Appendix.

A proper discursive treatment of political issues is often hampered by the fact that the respective opponents only use those fragmentary aspects of complex issues which support their case. Therefore, it is difficult to judge the relevance of their arguments for the global issue. In this way, frequently an antagonistic polarization of the debate rather than a consensus on adequate policies is achieved. The problem of bias in political argumentation is discussed in Kindt (1992b), where debates about the Gulf War are used as examples. In this paper, we are going to deal with the problem of bias in some more detail. As we cannot deal with all aspects of political argumentation within the limits of this paper, we would like to present answers to the following three questions:

(1) Which global aspects of the problem are treated and which are left out (= global bias)?

Global bias is to be detected and criticized at the macro-level of the text (sections, chapters), that is, as far as the unbalanced treatment or complete neglect of global dimensions of the problem under discussion is concerned.

(2) Which argument schemes are used to treat more specific aspects of the problem? Are the schemes used in a simplistic and one-sided way (= local bias)?

Local bias is to be analyzed at the micro-level of the text (sentences, paragraphs), that is, as far as the insufficient elaboration of specific arguments within a larger textual unit is concerned.

(3) How can we explain the increasingly aggressive climate of political discussion?

The treatment of our empirical data in Section 2 and 3 is intended to answer the first two of these questions. In Section 4, we shall sum up the descriptive results, give some answers to question (3) and finally try to formulate some recommendations to overcome the shortcomings of the political debate in Austria and Germany.

For our analysis, we have tried to integrate insights from various frameworks. First of all, ancient and modern rhetorical traditions provide attempts at classifying (everyday) arguments as instances of argument schemes. These schemes were called topoilloci by Aristotle $(1959,1960)$ and Cicero $(1951)$ within the Topical tradition of ancient rhetoric and dialectic, whereas they were termed 'techniques of argumentation' by Perelman and Olbrechts-Tyteca (1971) in their New Rhetoric. 
Moreover, we adopt the general strategy of the Pragma-Dialectic approach of Van Eemeren and Grootendorst $(1984,1992,1994)$, who want to reconcile descriptive and normative approaches in the study of argumentation (cf. also Kienpointner, 1996). They have developed a code of conduct for rational discussants and study everyday arguments as partial, more or less adequate realizations of these normative rules. Furthermore, they have formulated critical questions for testing the acceptability of instances or argument schemes found in everyday arguments. We also use the many elucidatory studies by Woods and Walton on fallacious arguments (e.g. Walton, 1992; Woods and Walton, 1989), which are based on perspectives of both formal and informal logic (cf. also Blair, 1992). In particular, Walton (1991) provides a useful background for the analysis of bias in political discourse. Walton lists five characteristics of bias in order of importance:

"1. Bias is a lack of appropriate balance or neutrality in argumentation. The problem here is that an arguer supports one side too strongly and/or too often.

2. Bias is a lack of appropriate critical doubt in argumentation. The problem here is a failure of restraint and/or failure to suspect the natural inclination to push for a point of view one supports.

3. Bias is a lack of balance or critical doubt appropriate for a given type of dialogue that a participant is supposed to be engaged in. It is not merely a lack of balance, but a lack of sufficient balance for a particular type of dialogue.

4. Bias is often identified with a particular position supported by an arguer.

5. Bias is often identified with an arguer's having something to gain - a personal interest in the outcome of an argument, e.g. a financial interest." (Walton, 1991: 19)

We add some remarks on the first three characteristics, which are considered the most important by Walton. The first characteristic makes intelligible the intuitive impression that biased arguments lack an impartial treatment of both sides of a question. However, a strong suppor: of one particular point of view need not be inherently fallacious. Therefore, Walton adds the second characteristic, which makes clear that bias is also connected with a specific weakness on the part of the speaker as far as a self-critical distance in relation to his or her own point of view is concerned. The third characteristic adds the important qualification that bias always has to be judged relative to a certain type of argumentative discourse. Of course, it makes no sense to look for impartiality in quarrels (eristic dialogues) or bargains (dialogues of negotiation); and letters to the editor cannot be criticized in the same way as scientific argumentation. In the following, we attempt to critically view the arguments in our sample according to standards which do justice to this particular type of argumentative text. That is, we judge particular arguments relative to standards which are actually followed in many other letters of our sample. Therefore, we criticize weaknesses of argumentation only if they are not found in all letters of our sample.

Bias is not restricted to everyday argumentation. It can also occur in scientific argumentation, especially where problems like political asylum are concerned, where everybody can be expected to have his or her own strong political convictions and commitments. So we have to deal with the problem of how we can avoid bias in our treatment of political argumentation. A first step towards the solution of this problem is to be aware of one's own point of view and to make it explicit. In this 
way, we can try to avoid an unjustified and exaggerated criticism of points of view and arguments which are opposed to our own opinion. Moreover, instead of hiding eventual bias in our analysis behind a pretended 'objective' perspective, we make it possible for the critical reader to judge whether or not we have succeeded in analyzing the texts of our sample as impartially as possible.

So what are our own political commitments? We are opposed to any kind of moderate or radical racism. As far as political refugees are concerned, we support a more liberal policy which does not accept the current severe restrictions for asylum-seekers. The protection of human rights for political refugees takes priority over economic interests.

\section{Theoretical background}

\subsection{Kinds of bias}

Like most discursive texts, political discourse in its monological form follows the general pattern of a three-part structure: introduction, main part and conclusion. Similar distinctions can be found in modern discourse analysis (cf. Henne and Rehbock, 1982: 186ff., 226ff.) and ancient rhetoric (Aristotle, 1959: 174f.; Cicero, $1951: 2.79 \mathrm{ff}$.). In the case of our letters on political asylum, the main part can very often be further divided according to the following prototypical structure: the status quo of society is described and evaluated as a negative situation which has to be overcome. Next, a more desirable state of society is outlined as a positive goal which should be attained in the future. Then, some possible political measures for reaching this goal are suggested. The conclusion following the main part usually contains an appeal which calls for action according to the policy advocated in the main part.

This structure partially corresponds to an argument scheme called 'pragmatic argument' by Perelman and Olbrechts-Tyteca (1971: 266ff.; cf. below Section 2.3). Given the limited space in letters to the editor, pragmatic arguments quite often appear in a reduced form. The same holds true of other instances of argument schemes appearing in the main part. This should not be criticized as local bias unless an argument clearly deviates from standards of preciseness and plausibility reached in many other letters. In this case, the following criticism is justified: "The suspicion in the case of an arguer who is badly biased is that the accused is not judging the worth of an argument according to the requirements of the argumentation scheme, but always reaching the conclusion, instead, that happens to support the point of view chosen in advance" (Walton, 1991: 3).

Apart from local bias, there is also the danger of global bias. The latter is the result of a neglection of global aspects or dimensions in the controversial issue. In our sample, three global aspects of the problem can be distinguished according to the temporal dimension: the discursive treatment of past, present or future aspects of the problem of political asylum.

Statements oriented towards the past offer causes, reasons and explanations for the negatively evaluated status quo. For instance, one reader writes: 
(1) Die Strömungen von Emigranten und Asylbewerbern sind mittelbare und unmittelbare Folge der früheren europäischen Kolonialpolitik.

'The flood of emigrants and asylum-seekers is an indirect and direct consequence of the former European colonial policy.'

A discussion orientated towarcls the past should provide prerequisites for answering the following question: what and how much should the persons involved contribute to a solution of the problems of the negatively evalutated status quo? The underlying logical context often remains implicit and can be described as follows: if certain persons are (jointly) responsible for a negative situation, they can be asked to contribute to the solution of the problems involved.

Discussions oriented towards the present time are characterized by statements which qualify the status quo in some detail. These qualifications, too, should be justified by suitable arguments. An example of such statements is the following passage:

(2) Im übrigen zeigt die Zahl der Anerkennungen, daß etwa 98 Prozent der Asylbewerber nicht politisch Verfolgte, sondern Wirtschaftsflüchtlinge sind.

'Besides, the number of persons accepted as asylum-seekers indicates that about 98\% are not political refugets, but economic migrants.'

Argumentation orientated towards the future offers statements about the adequacy of measures and tries to justify them whith arguments for subsequent policies. In the following example, a reader opposes possible constitutional amendments:

(3) Jeder weiß, daß wir den Einwanderer-Zustrom bremsen müssen. Dafür müßte das 'Asylverfahrensgesetz' ausreichen. Die Durchsetzung dieses Gesetzes ist wichtiger als eine Zerfledderung des Grundgesetzes mit Einzelheiten.

'Everyone knows that we have to slow down the influx of immigrants. The asylum laws should suffice for that. The efficient execution of this law is more important than the demolition of the constitution through details.'

Similarly, the textbooks describing and regulating debate tournaments at U.S. academic institutions distinguish global subjects ('stock issues') which have to be dealt with by the competing teams (cf. Freeley, 1986: 55ff.). However, in academic debate it is obligatory to treat all subjects in an equally detailed and sophisticated way.

The distinction of the three global dimensions is helpful for the explication of implicit argumentative sequences. It is also useful for the classification of passages as instances of argument schemes which are typical of the respective global subject. We will analyze specific schemes of argumentation in Section 2.3. But first, it is useful to provide a more general classification of the different ways of justifying a statement.

\subsection{Procedures of justification}

The efforts made by participants in discussions to justify their own statements or to refute those of their opponents can differ widely (cf. Kindt, 1992a). For the sake of simplicity, we will only discuss procedures of justification. 
A statement can be asserted without further justification, if it is trivially evident on the basis of an intersubjectively given perception, or if it is unanimously accepted within a speech community. In example (3) the expression Jeder weiß ("everyone knows') is used to allege unanimous acceptance of the statement.

Another type of justification is the argument of authority (cf. Aristotle, 1959: 127f.; Perelman and Olbrechts-Tyteca, 1971: 305ff.). According to this type of justification a statement is valid beyond reasonable doubt if it is confirmed by a qualitatively or quantitatively relevant group of persons with a great deal of competence in the respective area. Writers of letters to the editor can claim a status of authority if they are contemporary witnesses of certain events or have professional knowledge. Here are two examples:

(4) Ich selber habe die Geschehnisse während der Nazidiktatur im Dritten Reich miterlebt und bin deshalb der Meinung, daß der Grundgesetzartikel auf keinen Fall geändert oder abgeschafft werden darf.

'I myself was witness to the events that took place during the Nazi dictatorship in the Third Reich; therefore, I believe that the article of the constitution must not be changed or abolished in any way.'

(5) Wie traurig ist das rapide Zurückweichen der Sozialdemokraten, auf die bisher Verlaß schien, vor den Gegnern des Asylrechts für politisch Verfolgte. Als Richter fühle ich mich zur Kritik daran berufen, besonders soweit es um die Rolle der Gerichte in den neuen 'Ideen' geht.

'The rapid retreat of the social democrats, who have seemed so reliable thus far, is very regrettable! As a judge, I feel I am the right person to criticize this, especially as far as the role of the courts with reference to the new 'ideas' is concerned.'

Apart from the speaker, other persons or institutions are often appealed to as authorities. In the following example, both individual and institutional authorities are used:

(6) Der Bonner Korrespondent der Neuen Westfälischen weist in seinem Kommentar dankenswerterweise darauf hin, daß es hierzulande "einen harten Kern von Rechtsradikalen gibt', der keinen besonderen Anlaß braucht, um Jagd auf Ausländer zu machen, daß aber auch in den Köpfen anscheinend braver Bürger(innen) fremdenfeindliches Gedankengut schlummert. Diese deprimierende Tatsache wird zwar nach wie vor von den meisten Politikern und auch Journalisten geleugnet, wurde aber bereits vor mehr als zehn Jahren durch die von der damaligen sozial-liberalen Bundesregierung in Auftrag gegebene SINUS-Studie offenbar.

'In his commentary, the correspondent of the Neue Westfälische newspaper in Bonn laudibly refers to the fact that there is "a hard core of right wing radicals" in this country, who do not need a special excuse for hounding foreigners, but also that xenophobic ideas lie dormant in the heads of seemingly honest citizens 
as well. This depressing fact is still not acknowledged by the majority of the politicians and journalists, but was already clearly demonstrated more than 10 years ago by a SINUS report commissioned by the then social-liberal federal government.'

Another procedure of justification tries to support a point of view inductively, with the help of suitable examples and illustrations (Aristotle, 1959: 127; 1960: 303; Perelman and Olbrechts-Tyteca, 1971: 350). This procedure is used in the following passage:

(7) Tatsache aber ist, daß die weitaus meisten Flüchtlinge im ersten Halbjahr 199 I aus Ländern kamen, in denen schwerwiegende Menschenrechtsverletzungen begangen werden oder in a'enen blutiger Bürgerkrieg herrscht: Jugoslawien, Rumänien, Ostanatolien, Iran, Libanon ...

'It is a fact that in the first half of 1991 the vast majority of refugees came from countries where human rights are severely violated or where bloody civil wars are taking place: Yugoslavia, Romania, East-Anatolia, Iran, Lebanon ....'

Finally, another, particularly important procedure is to justify a point of view by premisses and inference rules, because in this way - at least in principle - deductive proof of the controversial point of view can be established. In the following example this technique is used for the refutation of a claim about the xenophobia of Germans. More specifically, the inference rule of contraposition (modus tollens) is applied:

(8) Was heißt eigentlich, die Deutschen haben grundsätzlich einen Ausländerhaß, wie man behauptet? Das Wort 'Ausländerhaß' müßte bei diesen Hassern ausgetauscht werden durch das Wort: 'Asylantenhaß'. Diese - meiner Meinung nach gesteuerten - autonomen Jugendlichen gehen doch zu 90 Prozent in die örtlichen 'Ausländerlokale' zum Essen! Warum? Weil sie einen Haß auf 'Ausländer' haben? Das kann nicht sein ...

'What does it mean that Germans have an inherent hatred of foreigners, as is maintained? The expression 'xenophobia', if applied to these people who are full of hate, should be replaced by the expression: 'hate of asylum-seekers'. $90 \%$ of these autonomous young people - who are in my opinion manipulated - regularly go to local 'foreigner restaurants'! Why? Because they hate 'foreigners'? That can't be the case ...'

The logical structure of this argument can be reconstructed approximately as follows:

If all Germans were xenophobic, German young people would not go to restaurants of foreigners.

$90 \%$ of German young people go to restaurants of foreigners.

Therefore: not all Germans are senophobic. 
The last procedure of justification is of vital importance in our analysis in the following sections. The reconstruction of discursive procedures underlying everyday arguments, however, is complicated by the fact that they are usually presented in a highly implicit form. An in-depth analysis and a critical evaluation are only possible if the various underlying logical structures are well known. Therefore, we need detailed typologies of argument schemes underlying everyday arguments like those in our sample.

\subsection{Argument schemes}

If the logical structure of argument schemes remains largely implicit in everyday arguments and mutual understanding in discursive dialogues is nevertheless possible, the meaning and use of these schemes must be highly conventionalized and form a stable part of the tacit knowledge of a speech community. Therefore, one of the main aims of empirical discourse studies is to identify the underlying logical structures and ways of realization of these schemes. In the following, we shall present argument schemes frequently found in our sample and illustrate their realization in discourse with some examples. In Section 3, we shall analyze two letters in more detail.

Many of the schemes we are going to examine can already be found in the Aristotelian catalogues of topoi (1960 passim, 1959: 119ff.). The way Aristotle presents the topoi in his Rhetoric and his Topics varies considerably. Still, it is possible to isolate two main functions: the selective function (hence the name of topos as a 'place' where arguments can be found) and the guarantee function. According to the first function, topoi are search strategies which enable the speaker to choose relevant arguments from the set of all possible arguments. The latter function allows an equation of Aristotelian topoi with inference warrants in the sense of Toulmin (1958): they guarantee the plausibility of the transition from the premisses to the conclusion (cf. De Pater, 1965; Green-Pedersen, 1984). In modern typologies, further empirically recognizable argument schemes have been added (e.g. by Perelman and Olbrechts-Tyteca, 1971). Moreover, many authors have tried to develop clear criteria for the demarcation of these schemes and formulated sets of critical questions as to their validity and plausibility (cf. Schellens, 1985; Van Eemeren and Kruiger, 1987; Warnick and Kline, 1992; Kienpointner, 1992a,b; 1993; Kindt, 1992a,b; Garssen, 1994).

We have distinguished three global dimensions in the asylum issue, which are treated more or less extensively in our sample (cf. above, Section 2.1): past, present, and future. Arguments oriented towards the past try to explain the present state of affairs. Therefore, many schemes deal with the causes and reasons of the criticized status quo. Some causal schemes (cf. already Aristotle, 1959: 132ff.) have the following structure:

If event $Y$ would not have happened without event $X, X$ is the cause of $Y$. Actually, $Y$ would not have occurred without $X$.

Therefore: $\mathrm{X}$ has been the cause of $\mathrm{Y}$. 
The following example is an application of this counterfactual way of reasoning, which is used to criticize political lethargy as the cause of the uprise of totalitarian regimes:

(9) Das, was während des Dritte'n Reiches an Bösem geschehen ist - die Verfolgung Andersdenkender, Krieg, millionenfache Vernichtung menschlichen Lebens wäre meines Erachtens nicht eingetreten, wenn bereits 1933 bei vielen der damaligen Zeitzeugen nichr Gleuchgültigkeit, Wegsehen, Weghören, Zurückziehen ins Private vorgeherrscht hätten.

'The evil things that occurred during the Third Reich - the persecution of opposers of the regime, war, the execution of millions of human beings - in my opinion would never have happened, if many of those who witnessed what was going on already in 1933 had not been so indifferent, had not looked away, had paid attention and not withdrawn into their own private world.'

Another variant of causal schemes uses abductive inferences (cf. Peirce, 1973): if event $\mathrm{Y}$ is entailed by $\mathrm{X}$, then $\mathrm{X}$ is at least a possible cause of $\mathrm{Y}$. This inference rule is applied in [10]:

(10) Mit Waffen auch aus deutscher Produktion wird ein Großteil der Flüchtlinge aus ihrer Heimat gebombt - und wir wundern uns dann, wenn sie vor unserer Tür stehen und unseren Scinutz erbitten.

'A majority of the refugees has been bombed out of their native land with weapons partially producecl in Germany - and then we are surprised when they turn up at our doorstep and ask for our protection.'

Another kind of causal reasoning tries to refute abductive inferences (cf. Aristotle, 1960: 132f.): the assumption of a causal relationship between $X$ and $Y$ is attacked by the presentation of the 'real' reason of Y, namely $Z$. In the following example this attack is combined with the charge that the "real' cause has been concealed:

(11) Minderheiten werden benutzt, wenn es darum geht, Defizite in unserer Gesellschaft zu verschleiern. Dann heißt es z.B., die Ursache für die große Arbeitslosigkeit, für die steigende Kriminalität oder für die wachsende Unsicherheit auf den Straßen seien die Ausländer.

'Minorities are used to conceal deplorable states of affairs in our society: for instance, it is claimed that the high rate of unemployment, the rising crime figures, and the growing insecurity in our streets are caused by the foreigners.'

If effects are caused by intentionally acting persons, the following question arises: did these persons freely choose to act (or to refrain from acting) in a particular way or were they forced to? In the first case, they are responsible for any negative consequences and have to justify their acts. Thus a speech act sequence 'reproach-justification' is opened (cf. Kindt, 1992b). In the following passage, the author of the letter emphatically tries to justify a certain group of persons (namely, the children of 
refugees), arguing that they are not responsible for the negatively evaluated status quo:

(12) Ich sehe Kinder vor mir, kleine fröhliche Wesen, die sich von anderen Kindern auf dieser. Welt kein bißchen unterscheiden. Die sind nicht gefragt worden, ob sie in Deutschland in einem Container oder Asylantenheim wohnen möchten, $o b$ sie ihre Kindheit in beengten Verhältnissen, gehaßt von Menschen, die sie gar nicht kennen, verbringen möchten. Diese Kinder haben nun wirklich nichts mit Arbeitslosigkeit, Wohnungsnot usw. zu tun ...

'I see children, happy little creatures, who are not at all different from other children in this world. They have not been asked if they would prefer to live in Germany in a container or an asylum-seeker's hostel, if they would like to spend their childhood in cramped conditions, hated by people they do not even know. These children really have nothing to do with unemployment, housing shortage etc. ...

A contrary position is taken in the following letter, where the asylum-seekers are seen as being responsible for the existing problems:

(13) Tatsache ist, daß die Mehrheit der zu uns kommenden Menschen nicht aus Gründen politischer Verfolgung, sondern aus rein wirtschaftlichen Erwägungen hierher kommt und sich unter Inanspruchnahme unserer sozialen Einrichtungen ein besseres Leben erhofft.

'It is a fact that the majority of the people who come to our country do not arrive because they are politically persecuted, but out of financial reasons, and that they hope for a better life with the help of our social institutions.'

Arguments oriented towards the present time often try to define or classify (elements of) the status quo or to compare it with similar situations and problems. Therefore, argument schemes containing definitions, part-whole or species-genus relationships are used.

Schemes containing definitions (cf. Aristotle, 1959: 126; 1960: 561ff.) often try to define an entity $\mathrm{X}$ by a definition $\mathrm{Y}$ in a way which makes certain conclusions favoring one's own position possible. In the following passage the author criticizes this strategy:

(14) Sprache ist verräterisch: Die der späten Achtziger und der jetzt Neunziger ist es auch. Klingt Asylant nicht ein wenig wie Strauchdieb? ... So werden aus 'Rabauken' plötzlich 'Ordnungstrupps verunsicherter Bürger' (O-Ton von einem Lokalpolitiker in Hoyerswerda), zusammengehauene Opfer mutieren pauschal zu Sozialhilfebetrügern).

'Language is very revealing: that of the late eighties, now the nineties, is, too. Doesn't 'asylum-seeker' equate a little bit with 'tramp'? ... Thus 'hooligans' become 'vigilante squads consisting of unnerved citizens' (these are the words of a local politician in Hoyerswerda), 'beaten-up victims' universally turn into 'social welfare swindlers', 
Schemes containing part-whole or species-genus relationships (cf. Aristotle, 1959: 128; 1960: 421ff.; Kienpointner, 1993) are used for inferences of subsumption and classification: properties of parts or species are transferred to the whole or genus and vice versa. For instance, the relative importance of entities can be demonstrated by their inclusion as part $\mathrm{X}$ into a whole $\mathrm{Y}$. In the following example, the importance of the number of refugees in Germany is shown to be insignificant, because the refugees form only a very small part of the population of Germany:

(15) Tatsache ist auch, daß sämtliche bei uns lebenden Flüchtlinge, ob anerkannt oder noch im Verfahren, weit weniger als $1 \%$ der Bevölkerung der Bundesrepublik ausmachen.

'It is also a fact that all refugees living in our country, whether already accepted or still under consideration, represent far less than $1 \%$ of the total population of the Federal Republic.'

Schemes of comparison rely on similarities or differences of entities (cf. Aristotle, 1959: 123; 1960: 371f f.). An important variant of these schemes contains an inference rule which is called 'rule of justice' by Perelman and Olbrechts-Tyteca (1971: $218 \mathrm{ff}$.). According to this rule, entities $X$ and $Y$ which are identical or similar according to a criterion $Z$, have 10 be evaluated and/or treated in the same way. The following example applies this appeal for justice:

(16) Jeder ausländische Arbeitsnehmer zahlt, genauso wie jeder deutsche, Sozialversicherungen, Steuern und nicht zu vergessen den Solidaritätsheitrag, der Dank dafür ist Ausländerfeindlichkeit.

'Exactly like every German worker, every foreign worker has to pay social security contributions, taxes and last but not least the solidarity contribution, all they get for this is xenophobia.'

A strategy counteracting appeals to the rule of justice tries to point out more or less important differences between the compared entities. If entities $X$ and $Y$, instead of being identical or similar, differ according to a criterion $\mathrm{Z}$, the application of the rule of justice is blocked; see the following example, where the writer tries to demonstrate that Germany is different from other countries as to size and, therefore, is not able to let in many refugees:

(17) Das verhältnismäßig kleine Deutschland ist eben nicht Kanada oder Australien. 'Germany, which is relatively small, cannot be compared to Canada or Australia.'

An important variant of the schemes of comparison is the 'a fortiori'-scheme (called topos of more/less or 'locus a maiore/a minore' in the ancient tradition, cf. Aristotle, 1959: 124f.; 1960: 407ff.; Cicero, 1951: 2.172; Perelman and OlbrechtśTyteca, 1971: 343). A general version of the 'a minore'-scheme could be formulated as a norm of action (cf. another version concerning the relative probability of states of affairs in Kienpointner, 1992b: 183): 
If even $\mathrm{X}$ has property $\mathrm{P}$, and $\mathrm{Y}$ 's having $\mathrm{P}$ is more acceptable than $\mathrm{X}$ 's having $\mathrm{P}$, then $Y$ should have $P$.

(Even) $\mathrm{X}$ has $\mathrm{P}$.

Therefore: $Y$ should have $P$.

Within the context of the refugee problem in Austria and Germany, this type of argument can be used to criticize a restrictive policy, because even poorer countries accept more refugees; however, it can also be applied to justify a restrictive policy, because even richer countries have adopted strategies for reducing the rate of immigration. This is shown by the following two examples:

(18) Im krisengeschüttelten Ungarn müssen seit den letzten Monaten viermal so viel Flüchtlinge versorgt werden, als unser 'sozialer' Minister Löschnak für ein Jahr zu kontingentieren gedenkt.

'In crisis-ridden Hungary, for the last few months four times as many refugees have had to be provided for than our 'social' minister Löschnak plans to accept in one year.'

(19) Selbst die USA, eines der reichsten Länder, haben schon vor Jahren den Zustrom von Einwanderern drastisch reduziert.

'Even the USA, one of the richest countries in the world, already reduced the influx of immigrants drastically years ago.'

Causal arguments oriented towards the future are quite often instances of the scheme of argumentation which has been called 'pragmatic argument' by Perelman and Olbrechts-Tyteca (1971: 266ff.; cf. also Aristotle, 1959: 129; Toulmin et al., 1984: 369ff.; Freeley, 1986: 181ff.). According to this scheme, the evaluation of an action $\mathrm{X}$ depends on the positive or negative consequences $\mathrm{Y}$ of $\mathrm{X}$. In its two basic versions, this can be presented as follows:

Action $\mathrm{X}$ leads to consequence $\mathrm{Y}$.

$\mathrm{Y}$ is desirable.

There are no other actions $Z$ with even more desirable consequences.

$\mathrm{X}$ has no or few negative effects.

Therefore: X should be done.
Action $\mathrm{X}$ leads to consequence $\mathrm{Y}$. $\mathrm{Y}$ is undesirable.

There are no other actions $Z$ with even more negative effects.

$\mathrm{X}$ has no or few positive effects.

Therefore: $\mathrm{X}$ should not be done.

Most of the time, actions have both positive and negative consequences. Therefore, all consequences should be considered and weighed up against each other. Action $\mathrm{X}$ can only be justified if the positive consequences outweigh the negative ones qualitatively and/or quantitatively. Likewise, $X$ can only be rejected if its negative effects are not outweighed by the positive ones (cf. Kindt, 1992b). As it is often difficult to consider all the direct and indirect consequences of an action and not 
neglect at least some of them, the danger of local bias in pragmatic arguments is considerably high.

In the following two examples, special emphasis is placed on the qualitatively most important consequences (20) and on possible indirect consequences (21):

(20) Wenn man zuläßt, daß auch nur eines dieser Rechte auf dem Jahrmarkt deutscher Eitelkeiten verschachert oder gar der Gewalt der Straße geopfert wird, bringt man die Freiheitsrechte insgesamt in Gefahr. ... Die Opferung auch nur eines Grundrechts ließe das Gespenst von Weimar wieder über Deutschlands Straßen und Plätze schleichen.

'If even one of these rights is permitted to be sold off at the German vanity fair, or sacrificed because of the street terror, the rights of freedom as a whole are endangered. ... Even the sacrifice of only one constitutional right would again let the specter of Weimar creep into the streets and squares of Germany...'

(21) Wer damit begint, Menschengruppen aus dem gerichtlichen Rechtsschutz nerauszunehmen, schafft damit gefährliche Einbruchstellen für die spätere Entrechtung immer weiterer Personenkreise.

'Whoever starts to remove social groups from the protection of the courts, creates dangerous weak points where ever more persons can be deprived of their rights.'

We have now presented an overview of types of everyday arguments occurring frequently in our sample. Of course, these types are only one step in the justification or refutation of a controversial point of view. They have their place in a sequence of complex argumentation where arguments are related directly or indirectly to the main issue of the discussion. Moreover, their verbalization is accompanied by strategies of foregrounding or backgrounding of relevant information. We will turn to these strategies in the next section.

\subsection{Strategic distribution of information}

Participants in a discussion can touch on themes they do not treat explicitly by giving partial information which requires some reading between the lines (cf. Van Dijk, 1992; 1993: 31f.; Gruber, 1993). For this purpose, they often use the following three strategies: selection of suitable lexical means of expression, backgrounding of incomplete information, foregrounding of incomplete information.

The first strategy consists in the choice of words which provide (e.g. with the help of conversational implicatures in the sense of Grice (1975)) information about a theme not treated explicitly. In the following example, the primary theme is the alleged inconsistency of the asylum policy of the FDP (= the German Liberal Party). Politicians of the FDP are accused of not practising what they preach (cf. Aristoteles, 1959: 132):

(22) Neben den komfortablen Bungalows aller FDP-Bundestagsabgeordneter sollte man Unterkünfte für Afrikaner, Asiaten und Zigeuner einrichten. Die liberalen 
Damen und Herren wären dann wohl sehr schnell vom Mitleid für die armen 'politisch Verfolgten' geheilt.

'Accommodations for Africans, Asians and gypsies should be built next to the comfortable bungalows of all FDP-members of the Bundestag $[=$ the Lower house of the German parliament, M.K./W.K.]. These liberal ladies and gentlemen would quickly be cured of their pity for the poor 'victims of political persecution'.'

The writer of this letter, G. Bittner, explicitly criticizes the behavior of members of the FDP; but by choosing the lexical item arm (= poor) and using quotation marks ('victims of ...') he also implies - possibly ironically - that the refugees are not really victims of political persecution and that they are possibly the main cause of the negatively evaluated status quo.

With the help of the second strategy, the writer explicitly introduces the side theme, but refrains from expanding it in the following discourse. Thus, it is backgrounded. In the following letter, political measures suggested by the then German minister of the interior, Schäuble, are criticized:

(23) Kennt Schäuble die Möglichkeiten des Asylverfahrensgesetzes nicht oder will er nicht darüber sprechen - aus ganz anderen Gründen, die mit der Bewältigung der Asylantenflut gar nichts zu tun habe?

'Doesn't Schäuble know the asylum laws or doesn't he want to talk about them - for entirely different reasons, which have nothing to do with the influx of asylum seekers?'

The parenthetical comment about personal motivations on the part of the minister are not taken up in the following context. It is only at the end of the letter that the writer provides some further information which implies that Schäuble suggested changes of the constitutional laws in order to annoy the SPD $(=$ the German Social Democratic Party).

The third strategy places explicit information on themes which in the main part are not treated at the beginning or the end of the letter. Thus in a letter which mainly analyzes the present status quo, possible causes are only presented at the end. The prominent position of the last sentence in the published version of the text foregrounds this causal explanation:

(24) Solange aber junge Leute nicht heiraten können, weil sie keine bezahlbare Wohnung finden, solange alleinerziehende Mütter aus gleichem Grund in Notunterkünfte abgeschoben werden, solange der letzte deutsche Kleinstrentner under der Armutsgrenze lebt, solange hat der Bürger ein Recht auf Angst und Sorgen, denn unsere 'vom Volk gewählten Politiker' sitzen in Bonn und reden, reden und reden!

'However, as long as young people cannot get married because they can't find an affordable apartment, as long as single mothers are pushed away into temporary accommodation, as long as there is one German retiree living below the 
poverty line, the citizen has a right to be afraid and worried, because our 'politicians elected by the people' are sitting in Bonn and only keep on talking, talking, talking!)'

On the one hand, these strategies can reduce the danger of bias because they provide implicit or explicit information on side themes not covered in the rest of the letter. On the other hand, they often have the function of transporting positions and judgments without giving explicit arguments which could be attacked and refuted. For instance, in example (24) a reproach is verbalized, but not justified. Thus the readers could more easily be influenced by a potentially biased statement.

\section{Detailed analysis of two letters to the editor}

We chose the two letters analyzed in this section in detail according to the following criteria:

(a) They should cover a broad range of themes, that is, they should not be restricted to isolated cases or events.

(b) They should not be too short, which would automatically entail some kind of global bias, that is, the neglect of important global dimensions of the problem under discussion; nor should they be too long, because that would make a detailed analysis impossible within the limits of this paper.

(c) They should be examples of everyday argumentation. Therefore, we chose letters of ordinary people who are not dealing with asylum problems professionally.

(d) They should represent contrary points of view, namely a rather liberal and a rather restrictive position concerning refugee policy.

Following these criteria, we chose the letter Straffällige müssen abgeschoben werden ('Criminals have to be deported'), written by Andreas Krämer, Gießen (in Frankfurter Rundschau, 16.10.1991; henceforth abbreviated as L1), and the letter Nur eine kleine Hilfe ('Only a little help') by Uwe Tünnermann, Lemgo (in Neue Westfälische, 24.9.1991; henceforth abbreviated as L2). The full texts and translations are given in the Appendix, Section A2.

In our analysis we will not refrain from giving critical comments on the argumentation of the authors. However, ve are not going to criticize them for deviations from high standards of scientific argumentation. Walton (1991: 4ff.) justly remarks that every argument can only be judged as biased relative to a type of argumentative context. Letters to the editors are not intended as scientific inquiries into a problem. Moreover, the writers do not have enough space to treat a problem exhaustively. Besides, quite often the editors of the journal or magazine reserve the right to omit parts of the letter. This is exactly' what seems to have happened with two passages of L2. But still, it is justifiable to criticize arguments in letters to the editor if they are globally or locally biased in comparison to many other letters in the sample, that is, according to standards of argumentation which seem to be followed frequently in this type of argumentative discourse. Moreover, authors of letters to the editors often explicitly claim that they (are trying to) argue objectively or impartially (cf. our 
analysis of L1 and L2 below). Especially these passages can be criticized if they do not follow standards of critical discussion like, for example, those established by Van Eemeren and Grootendorst $(1984,1992)$. If the authors themselves claim a reputable standard of argumentation, they cannot be excused in the same way as the writers of other letters who use their text simply as a means of political polemics or propaganda or want to compensate for strong emotional tensions. Finally, we would like to repeat (cf. Section 1) that we do not claim absolute objectivity in this case and only try to analyze the letters as impartially as possible.

In the following, we first present the argumentative macrostructure (cf. Van Dijk and Kintsch, 1983: 15) of L1 and L2. This reconstruction of the basic propositions conveyed by the texts will be used as a starting point for critical comments on possible global bias.

According to the macrostructure depicted in Fig. 1, L1 can be characterized as a text which mainly gives reasons for the deplored status quo and suggests measures for improving the situation. Krämer almost completely refrains from analyzing the present situation. Differently from many other letters in the sample, Krämer does not try to define crucial concepts nor to classify or compare the status quo (using relationships of species-genus or part-whole or similarities and differences). Especially problems of justice, which are treated in many letters of comparable length, are almost entirely neglected. Therefore, L1's almost exclusive orientation towards the past and the future can be criticized as a global bias. However, $\mathrm{Ll}$ is a reaction to an earlier article Rechtsextremismus weit verbreitet (Attitudes of the extreme right are widespread) in Frankfurter Rundschau (26.9.1991). The analysis of the status quo in this earlier article seems to be included implicitly. In our detailed analysis of $\mathrm{L} 1$, we will have to consider whether the abstention from an explicit treatment of the present situation is dysfunctional also for the claims concerning possible reasons and measures.

The macrostructure of L2 can be reconstructed as in Fig. 2. As can clearly be seen, Tünermann treats all global dimensions of the problem. However, the focus of his treatment is clearly directed towards the present and the past situation. Measures suggested for the future are not compared with the possible alternatives or evaluated as to negative consequences. The negative consequences expected by Krämer are apparently not a central issue for Tünnermann. Therefore, also L2 can be criticized as globally biased: it is too strongly orientated towards an analysis of past reasons for the status quo and questions of justice in the present situation.

In our detailed analysis of $\mathrm{Ll}$, we shall mainly be dealing with three problems:

(1) How are the schemes of argumentation verbalized?

(2) Which strategies of foregrounding or backgrounding are used?

(3) Which local forms of bias and/or other forms of uncorrect or fallacious argumentation can be detected?

\section{I. Analysis of $L I$}

\subsubsection{Verbal strategies}

Strategies of verbalization are used to make one's own arguments as strong as possible. They can be used to reject possible objections to one's own arguments 


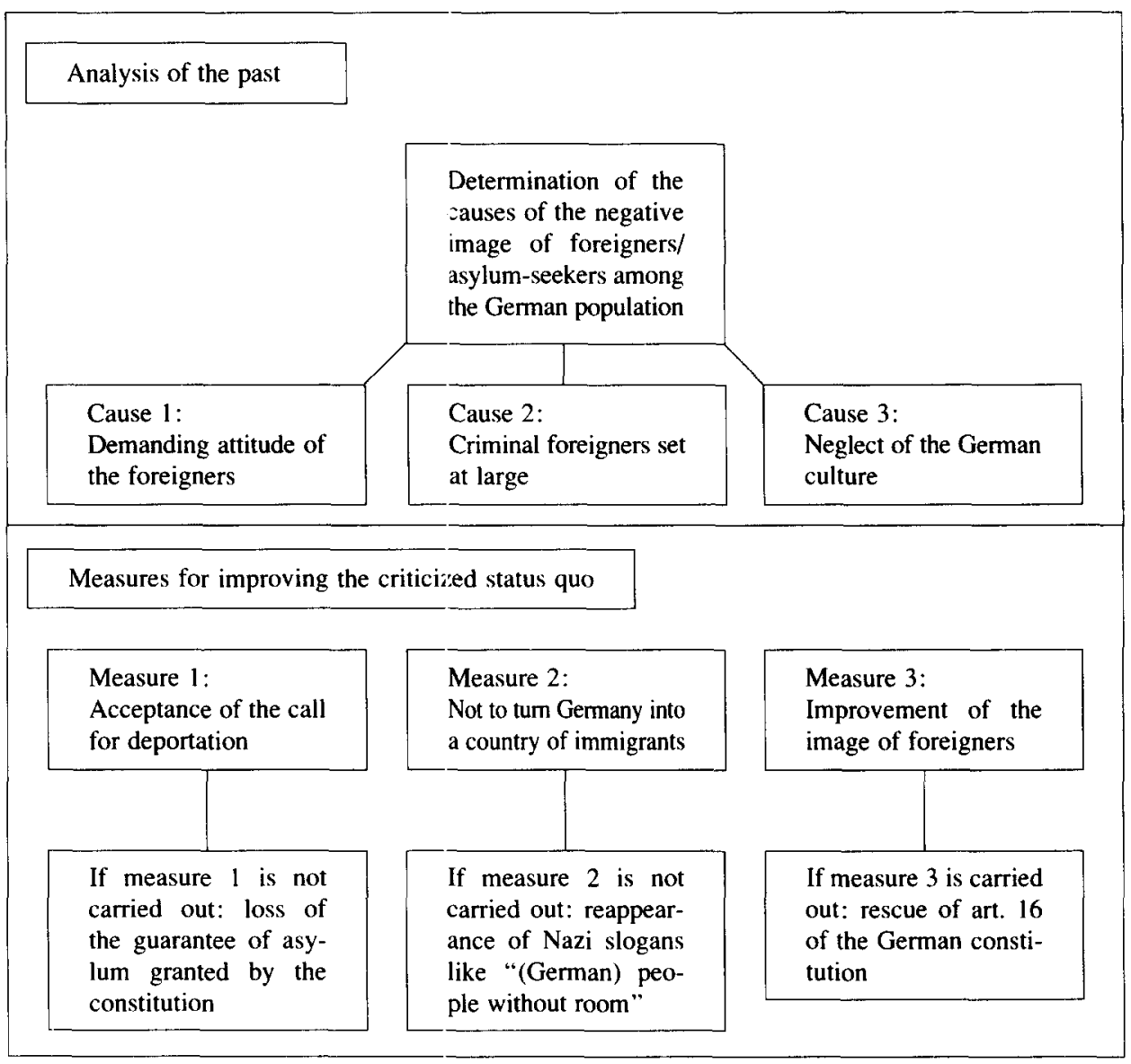

Fig. 1

(defensive strategies) or to produce the impression that one's own arguments are (almost) evident proof (offensive: strategies).

An example of a defensive strategy is the opening sentence of Krämer's letter: So entsetzlich die Vorkommnisse ... sind ('However terrible the events ... are'); this is an instance of the strategy called 'concessio' (concession) in ancient rhetoric (cf. Quintilian, 1970: 500; Van Dijk, 1993: 93ff.). This rhetorical strategy consists in conceding a weak argument in order not to have to defend it in detail. Then the speaker goes on to argue in favor of a stronger point of view. Krämer concedes that the violent attacks on asylum-seekers' hostels are dreadful in order to prevent the impression that he would play down these events. The latter could not be justified in a democratic society.

Similarly, with the formulation So ist es keinesfalls 'rechtsextrem' ('It is, therefore, in no way an 'attitude of the extreme right')' in the third paragraph he wants to prevent his urgent recommendation of the deportation of refugees from being evalu- 


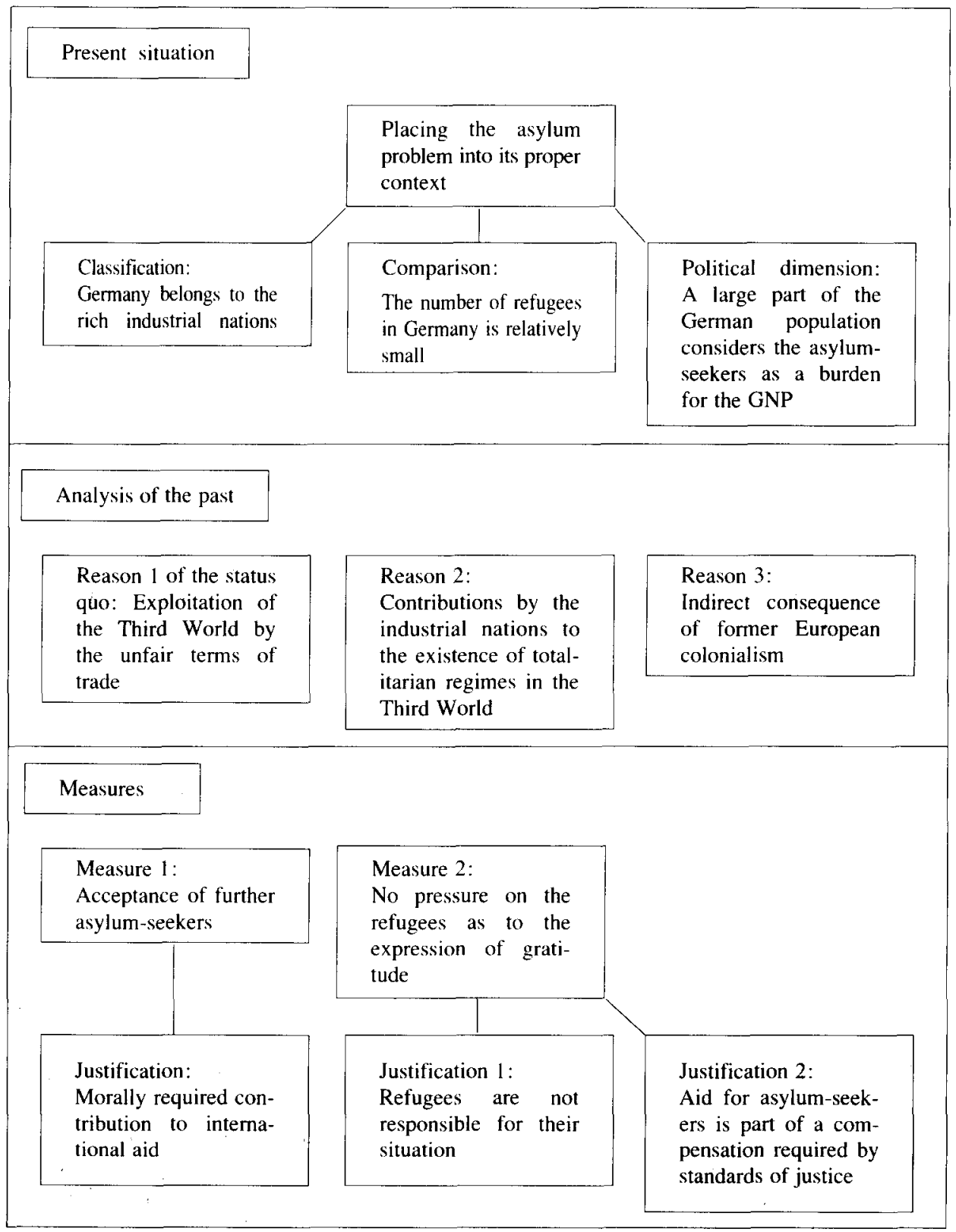

Fig. 2

ated negatively as a right wing extremist's point of view. Preventive strategies are called 'praemunitio' (preventive defense) in ancient rhetoric (cf. Quintilian 1970: 485). This technique is atso used in the immediately following defense of this mea- 
sure: Dies sollte ... nicht so einjach ... abgetan werden ('This should not simply be dismissed'). At the same time, Krämer's continuous attempts at dissociating himself from positions of the extreme right are used as strategic means of positive self-presentation (cf. Van Dijk, 1992; 1993: 76ff.).

Offensive strategies try to present one's own arguments as maximally relevant and/or conclusive. To reach this aim, Krämer presents the global focus of his argumentation, namely, the negative image of the asylum-seekers, as maximally pertinent to the asylum discussion. A.ccording to his formulation in the first paragraph, it is inevitable to think about the low degree of acceptance of the refugees (... so kommen wir nicht umhin, darüber rachzudenken ... 'we cannot avoid considering ...'). In the second paragraph, he considers the demanding attitude of the foreigners as one reason for their negative image. This argument is presented as trivially true: So ist doch letztlich unbestritten ... ('After all, it cannot be denied ...'). However, this formulation is mildly mitigated by the particles doch letztlich ('after all').

Another offensive strategy consists in presenting the own point of view as relevant for all or the vast majority. This strategy is realized by the use of the 'inclusive we': for example; Krämer uses wir in this at the end of the third paragraph: Wir riskieren ... zu verlieren ('We risk losing ...').

\subsubsection{Distribution of information}

As we have seen above, part of the information conveyed by the text is quite often backgrounded. The backgrounded information can trigger inferences which the reader is supposed to make. However, a more explicit presentation of the inferences could be detrimental to the position of the author. Thus, backgrounding information serves a double purpose.

In the second paragraph of L1, Krämer, using a parenthesis (- aus dessen Sicht 'according to his view'), restricts the claim about the demanding attitude of the foreigners to Mr. Average (Otto Normalverbraucher, literally: 'Otto Average Consumer'). However, by simply using the name and a parenthesis, Krämer backgrounds this restriction. It is only a secondary theme, the importance of which is thereby reduced. Compare other possible formulations like 'Of course, the demanding attitude exists only in the mind or Mr. Average', which would express the restriction with much more informative weight. In this way, Krämer can admit that his argument is not tenable for all Gerrnans without having to withdraw it completely.

In the third paragraph, the use of the expression Zauberwort ('magic word') creates an implicature which connects the right of asylum with the influx of (criminal) desperate people: magic words like 'asylum' create an impression of a paradise in Germany, which attracts innumerable people without hope. Again, Krämer could not have claimed this implicature explicitly without weakening his own arguments: after the violent attacks on refugees it has become difficult to claim that Germany is a magic kingdom for asylum-seekers.

The last sentence of $\mathrm{L} 1$ calls for active participation by the foreigners in Kramer's program in creating a better image for the refugees (Hierzu bedarf es aber auch der Mitwirkung der Ausländer). Krämer leaves possible ways of participation implicit. In this way, it is easier for the readers of L1 to share Krämer's point of view because 
an explicit mentioning of possible measures could include kinds of policies not acceptable for many of them.

\subsubsection{Schemes of argumentation}

The quality of the arguments in a text can be evaluated in two steps: firstly, they can be criticized as locally biased arguments because they are incomplete instances of an argument scheme. This is the case when relevant premisses are left out, for example important causes or consequences.

Secondly, they can be criticized as incorrect applications of an argument scheme because they create misunderstandings due to the use of ambiguous expressions or contain hasty generalizations or falsely present temporal succession as causal relationships or are connected with unjustified personal attacks (cf. Van Eemeren and Grootendorst, 1992).

We will begin with an evaluation of the completeness of the argumentation. At the beginning of Ll, Krämer uses causal arguments. These can be criticized as incomplete because Krämer does not discuss or at least mention further possible causes for the negative image of foreigners, for example:

(a) insufficient strategies by the politicians,

(b) deeply rooted prejudices against foreigners,

(c) persuasion by emotionalizing propaganda directed against foreigners,

(d) insufficient information about the situation in the developing countries and the individual and collective fate of asylum-seekers before their arrival in Germany. Without consideration of these causes, which are treated explicitly in many other letters in our sample, Krämer's analysis necessarily remains incomplete. He could at least have stated that there are further possible causes for the negative image. Thus, the omission of further causes cannot be simply ascribed to the lack of space within a particular text type like letters to the editor. Furthermore, the local bias resulting from the neglect of other possible causes of the status quo also reduces the plausibility of the measures suggested by Krämer later on.

Of course, Krämer's concentration on measures to improve the image of foreigners could be justified if he did not want to suggest an overall solution of the problem. However, the opening sentence in the last paragraph of his letter creates the impression that the improvement of the image would be the main step towards a solution (Das Ziel zur Rettung des Artikels 16 GG muß sein, wieder eine breite Akzeptanz in der Bevölkerung zu schaffen. 'In order to save article 16 of the constitution [= which grants the right of asylum, M.K./W.K.], one needs to recreate broad foreigner acceptance by the population'). Moreover, even if Krämer only wanted to provide a partial solution to the problem, he could have strengthened the relevance of his suggestions by comparing the number of foreigners with the total population of Germany or by giving data concerning the number of criminal foreigners in proportion to criminal German citizens.

Finally, further measures, which are treated repeatedly in other letters, are simply missing in Krämer's discussion of possible policies:

(a) a better explanation of the asylum laws by the politicans;

(b) job opportunities or even obligatory work for asylum-seekers, 
(c) reduction of the welfare contributions for the refugees to the necessary minimum.

As far as the correctness of the arguments in $\mathrm{Ll}$ are concerned, we have to distinguish three aspects:

(a) The sincerity of Krämer's personal statements cannot be judged by looking at the text alone. Moreover, of ten it is not easy to tell how we have to interpret statements which are not explicitly marked as subjective. Therefore, in these cases a judgment of correctness is not possible.

(b) Most statements in $\mathrm{Ll}$ are formulated as if they were accepted by all or most members of the German speech community. Again, it would be very difficult to judge the correctness of these assumptions. It would be particularly difficult to decide whether the alleged facts really are the (only) causes of the negative image of foreigners.

(c) Therefore, within the limits of a textual analysis, a more feasible way of analysis is the critical assessment of the correctness of the inferences drawn by Krämer. The truth and the sincerity of the statements used as premisses are accepted provisionally.

This does not mean that the facts presupposed by Krämer are uncontroversial. In the first paragraph of $\mathrm{L} 1$, he asks why in der nahezu gesamten deutschen Bevölkerung die Akzeptanz gegenüber Ausländern/Asylbewerbern ... gering ist. This presupposes that almost all Germans have a negative view of foreigners. However, the title of the article in the Frankfurter Rundschau which Krämer quotes only says that right wing extremism is widespread (Rechtsextremismus verbreitet). Krämer's presupposition could be criticized as an instance of the fallacy of hasty generalization. However, this generalization is necessary for his further arguments. Only if the vast majority of the population really has a negative attitude towards foreigners, can Krämer's conclusions be justified: he considers the improvement of the negative image as the main problem to be solved.

The correctness of Krämer's inferences suffers particularly from the fact that he does not sufficiently distinguish between foreigners in general and asylum-seekers. In the passage quoted above he treats foreigners and asylum-seekers as one group (Ausländer/Asylbewerber). In the second paragraph he talks about foreigners (Ausländer), but seems to have asylum-seekers and economic migrants in mind. In the third paragraph he mentions foreign drug dealers, gamblers, thieves and gangs (ausländische Drogendealer, Hütchenspieler, Diebes- und Unterweltbanden), which cannot be equated with political refugees in the sense of $\$ 16$ of the constitution, which grants asylum. But this is exactly what Krämer does when he falsely claims that many of the respective criminals are attracted to Germany by the magic word 'asylum' (das Zauberwort 'Asyl'). Therefore, even if this statement is true about the criminals referred to, it cannot be used to infer the conclusion concerning the deportation of criminal asylum-seekers. Due to the ambiguity of crucial terms used by Krämer, the logical relationship between his premisses and his conclusion remains unclear and his interence is, therefore, not correct.

Krämer's sloppy use of Ausiänder could be justified because he talks about the political views and emotions of the German citizens, who do not carefully distin- 
guish different senses of the word either. This is the way in which the negative image of specific groups of criminal foreigners is transferred to the refugees. However, any discussion about possible political measures to improve the situation should avoid confusing clearly different groups. Writers of other letters in our sample, differently from L1, do attempt to distinguish 'foreigners' in general from 'refugees', 'asylum-seekers' and 'economic migrants'.

Twice, Krämer uses instances of the pragmatic argument (cf. Section 2.3.) to justify political measures through the negative consequences which will follow if the measures are not realized.

In the third paragraph, he justifies his call for deportation with undesirable consequences for the negatively evaluated status quo. His inference, which proceeds in three steps, can be reconstructed as follows (for the sake of brevity, we only provide the warrants, that is, the inference rules justifying the step from the premisses to the conclusions):

(1) If the deportation of criminal foreigners is not undertaken, the negative image of asylum-seekers will remain unchanged. This inference rule remains implicit, but has been justified by Krämer in the preceding context. Therefore, the rule, which is necessary for the correctness of the inference, can be supplemented. However, as we have shown above, this inference rests on a premise ('Criminal foreigners cause the negative image of asylum-seekers') which confuses different groups of foreigners.

(2) If the negative image of the refugees remains unchanged, $\$ 16$ can no longer be carried out. This step is explicitly stated by Krämer (cf. Jedes Recht kann nur solange durchgesetzt werden, wie es ... trifft).

(3) If $\$ 16$ can no longer be carried out, it runs the risk of being abolished. Again, this inference rule remains implicit. But Kramer can correctly suppose that his readers know the rule, given the many recent requests for the abolition of $\$ 16$ from the constitution.

All in all, Krämer's argumentation seems to be a correct application of the pragmatic argument scheme. However, as we have seen, some premisses of the inference are problematic due to an ambiguity of crucial terms. Moreover, the presupposed causal relationship between the foreigners' negative image and the abolition of $\$ 16$ remains doubtful because some further possible causes are not considered.

Krämer uses a second instance for the pragmatic argument in the fourth paragraph. This time, he argues by pointing out negative consequences if certain political measures are taken: If Germany is made an immigration country through certain legal measures, right wing theories of Volk ohne Raum (= Hitler's claim: 'Germans do not have enough space to live') can be expected to be revived.

Krämer also seems to imply that further negative consequences would go hand in hand with these extremist theories. However, he himself does not seem to consider this argument to be sufficient because he adds an argument of comparison: Germany is considerably smaller than traditional immigration countries. But again, his use of the pragmatic argument seems to be basically correct. Still, he can be criticized for not discussing possible advantages of a more liberal immigration policy, which could outweigh negative effects, like the creation of dubious theories by small 
groups of the extreme right. To a certain extent, this incompleteness makes Krämer's argument biased. Moreover, his vvay of warning about the danger of right wing reactions can be accused of being a kind of concealed racist strategy: this way, restrictive measures can be justified at any time as the lesser of two evils (cf. Van Dijk, 1993: 99ff.).

To sum up, we conclude that our detailed analysis of L1 has shown a number of weaknesses. The plausibility of K.rämer's arguments is reduced by two main factors: the incompleteness of some of its arguments make L1 locally biased, the correctness of the inferences in $\mathrm{Ll}$ is partially endangered by the ambiguity of crucial terms.

\subsection{Analysis of $L 2$}

In our treatment of $\mathrm{L} 2$, we shall deal with our three basic questions simultaneously. We recall that the questicns are: (1) the verbalization of arguments, (2) the informational strategies, (3) the plausibility of the arguments. Tünnermann's letter has apparently been shortened by the editors of the Neue Westfälische in three places. However, this seems to tre relevant for our discussion of possible local bias only in one instance, namely, at the end of the letter.

In the first two paragraphs of L2, Tünnermann uses a technique called 'dissociation of concepts' by Perelman and Olbrechts-Tyteca (1971: $411 \mathrm{ff}$.). In its most general form, it consists in refuting a position by pointing out that it relies on 'appearance' rather than 'reality' (ibid.: 415).

In the first paragraph, Tünnermann contrasts the position based on stereotypes of the mass and mass media ('appearance') with expert knowledge about the status quo ('reality') mentioned in the second paragraph. He points out his reserve against such stereotyped attitudes by using quotation marks and the subjunctive (als stünde Deutschland in der 'Asylantenfrage' vor einem Überlebensproblem. 'The impression that Germany is facing problem: of survival because of the 'asylum-seekers' question')'. Moreover, the use of the lexical item Überlebensproblem (problem of survival) can be analyzed as a backgrounded criticism. That is, Tünnermann implicitly criticizes exaggerated claims in the asylum discussion: quite often, causal 'arguments of direction' (Perelman and Olbrechts-Tyteca, 1971: 281ff.) are used to support the view that a liberal asylum-policy ultimately leads to a catastrophe. His use of the form Bundesbürger(innen! (male and female citizens of the Federal Republic) makes clear that Tünnermann is also opposed to sexist norms of usage. At the same time, he indirectly introduces hirnself as someone who knows more than the average citizen.

In the second paragraph, Tünnermann tries to prove that the facts refute the stereotype of an apparently disastrous status quo. To do this, he uses two arguments; First, he classifies Germany as a rich industrial nation. Possible counter-arguments against this instance of a species-genus argument scheme are preventively blocked by the qualifications trotz ihrer immensen finanziellen Verpflichtungen ('despite its immense financial commitments') and nach wie vor ('notwithstanding the economic changes in Germany'). Tünnermann's argumentation can be criticized because it does not provide comparisons 'with the relative wealth and financial problems of 
other 'rich industrial nations'. Moreover, it falsely pretends that 'rich industrial nation' is a precise, clear-cut category. Therefore, it is not compelling to conclude that a rich industrial nation cannot have problems of survival.

Secondly, Tünermann presents statistical evidence which puts the absolute number of refugees in Germany into perspective: $1 \%$ of all refugees in the world does not seem to be much. Moreover, he quotes Amnesty International as a reliable source of the data, thereby using an argument from authority (cf. above Section 2.2). The following argument is an instance of the a fortiori-scheme (cf. above 2.3): if even developing countries have to cope with many more asylum-seekers, Germany should not worry about $1 \%$ of them. Both arguments suffer from incompleteness because Tünnermann does not present data concerning other industrial nations and does not mention the huge problems caused by the influx of refugees into neighboring Third World countries.

The lack of a precise demarcation of crucial concepts and the incompleteness of Tünnermann's argumentation in the second paragraph justifies a criticism of local bias. Tünnermann cannot simply be excused by a lack of space; for instance, in many other letters of comparable length the financial situation of Germany is dealt with explicitly and compared with that of other indistrial nations.

In the third paragraph of L2, Tünnermann treats a further central aspect of the asylum discussion: even if there is no doubt as to the survival of Germany, he has to deal with the fact that many German citizens cannot understand why they have to bear the costs incurred by the refugees. The strong emotions involved are only hinted at by the lexical items wurmt and fleißig: many Germans are annoyed because part of their money, which they have worked hard for, in used for the refugees. However, Tünnermann does not deal explicitly with the emotional problems of these groups of the German population, he rather tries to refute their assumed cost-benefit reasoning, which can be reconstructed as follows:

If we pay for the refugees without getting anything in return, this situation is not acceptable.

We pay for the refugees without getting anything in return.

Therefore: This situation is not acceptable.

Tünnermann criticizes this way of reasoning with the following general type of objection: relevant premisses have been left out; hence, the argument is incomplete, which means that it is locally biased (cf. Kindt, 1992a: 114).

Tünnermann offers three factual claims to show that his criticism is justified. All claims try to demonstrate that Germany shares some responsibility for the economic and historical facts which have led to the asylum-problems. Like Krämer, he uses the 'inclusive we' to make the emotional impact of his charge stronger. The same function is fulfilled by the negatively connotated nouns Ausbeutung/ Produktionsdiktate/Kolonialpolitik (exploitation, constraints of production, colonialism). Tünnermann mitigates his accusation by claiming only co-responsibility for Germany. Still, a more balanced view should have considered the considerable 
involvement of local rulers and politicians in the exploitation of people in Third World countries.

In the last paragraph, Tünnerrnann draws conclusions which are wholly based on variants of the rule of justice (cf. above, Section 2.3.):

(a) every nation has to contribute an adequate amount towards international aid,

(b) the countries who have more should help those countries who have less,

(c) the Germans, at least partially, have to compensate for their profits due to the unfair terms of trade with their financial aid.

Tünnermann has provided some background for these arguments in the preceding paragraphs: he has argued that Germany's contribution to international aid is not unreasonably high (second paragraph) and that there are economic and historical reasons which compel Germany to compensate its (earlier) profits made in the Third World. Therefore, his application of the rule of justifice is basically correct.

Arguments based on the rule of justice have to show the equivalence of the compared things, persons, situations etc., however. Given the fact that many refugees come from the former Eastern Eloc, the rule of justice does not apply here, at least not in the same way as in the case of refugees coming from the Third World. Moreover, again using the 'inclusive we', Tünnermann does not even try to distinguish between different degrees of responsibility of subgroups of the German population (e.g. owners of big enterprises in contrast to the mass of the population). These differences should have resulted in a less apodictic use of this argument scheme.

Finally, it can be criticized that Tünnermann justifies possible measures for improving the status quo only by using moral arguments. That is, he does not consider the possible consequences of the suggested measures nor does he mention the possibility of removing possible causes of the deplored status quo. In general, the arguments offered by Tünnermann suffer from the fact that he does not try to combine his remarkable ethical standards with an analysis of advantages and disadvantages of possible measures and their alternatives.

To sum up, we can conclude the following: though we are more sympathetic to the position defended by Tünnermann, L2, like L1, contains several flaws and weaknesses of argumentation. While Krämer's L1 is strongly centered round the feelings of the German people and pragmatic arguments about consequences of possible measures, Tünnermann's L2 deals mainly with Germany's moral obligations and arguments based on the rule of justice. Both letters often lack appropriate balance. They are undoubtedly biased to a certain degree. While it may have been impossible for them to deal with every aspect with sufficient sophistication, Krämer and Tünnermann could at least have mitigated their claims a little.

\section{Conclusion}

We have tried to present a framework for the analysis of argumentation which combines theoretical and empirical approaches. We have studied the problem of bias in political argumentation on the basis of a sample of letters to the editor. Of course, the limited space makes it difficult for the writers of these letters not to produce 
locally or globally biased arguments. However, the analysis of other types of political discourse clearly shows that bias is a general problem in political discussions (cf. Kienpointner, 1992a: 250ff.; Kindt, 1992b; Walton, 1991 on bias in oral and written discourse in newspaper articles, TV-discussions, election campaigns etc.). In the following, we will list a few possible explanations for the fact that bias is so frequent in political argumentation:

(a) it is cognitively simple and emotionally more pleasant to recognize only those aspects of a problem which are important to oneself and support one's own point of view. In this way, cognitive dissonance and unpleasant feelings of shame and guilt are avoided or at least reduced.

(b) Prevailing styles of education and communication in our culture enhance antagonistic rather than cooperative procedures in the solution of conflicts. The resulting competitive styles of argumentation are prone to produce biased arguments.

(c) Many social and political problems are so complex that an adequate treatment is almost impossible on the basis of everyday argumentation.

An approach like ours, which is directed at descriptive and normative goals, should provide strategies and recommendations for overcoming the problems posed by the factors listed above. What, then, are viable solutions for improving the quality of political argumentation?

First of all, it has to be stated that it is neither possible nor necessary that political argumentation in its everyday form has to treat every aspect of the respective problems in a detailed way; some degree of global bias is inevitable, given the various limits of time and space. This inevitable bias has to be compensated for by appropriate political structures which grant pluralism and free expression of political opinions. In democratic societies, the writing of discursive texts, for example editorials or letters to the editor, can be seen as a cumulative process where only the collection of all texts written from widely diverging perspectives can be seen as a sufficiently balanced treatment of complex political problems: it results in a compensation of individual bias. Therefore, individual writers like those in our sample may choose certain dimensions of the problem and neglect others. But they should become aware of the fact that they contribute only partial solutions to the problem. Moreover, they should avoid drawing hasty conclusions without qualification. If Krämer and Tünnermann had followed this recommendation, they would have stated that their concentration on pragmatic (L1) or justice-oriented (L2) arguments, respectively, was only a contribution towards a partial solution of the complex asylum problem.

Secondly, bias in political argumentation could be mitigated if people were willing to avoid the use of crucial political terms with strong positive or negative connotations. Usually, these terms are used because they favor one's own position: if somebody is an 'economic migrant' rather than a 'political refugee', he or she does not deserve asylum; if somebody is a 'fascist' rather than a 'conservative', his or her political arguments need not be taken seriously in a democratic society. Therefore, in political debates 'semantic fights' are quite often carried out by participants who want to push through their own rules of usage. Many political discussions could become more fruitful if the participants were willing to use impartial terms wherever available. 
Thirdly, the improvement of the standards of political argumentation requires institutional changes in our system of education. If people are to become ready to produce balanced arguments and to behave cooperatively in discussion, this ability has to be formed at school and in other pedagogical institutions. It should be trained much more than it is the case nowadays, for example in the educational system of Austria and Germany. Similar claims hold true for many other countries. It is strange to see the following discrepancy: on the one hand, modern societies have become completely dependent on successful communication; on the other hand, differently from the Ancient World and the Middle Ages, wide-ranging and efficient training of the techniques of argumentation are widely neglected in the educational institutions (perhaps with one major exception: the debate tradition in England, the U.S.A., the Netherlands and some other countries). Important political issues like the asylum problem often lead to tedious and frustrating decision procedures. This makes clear that deliberate attempts to improve the practice of argumentation are necessary.

A change in educational policy is also suggested by the alarming increase of nationalism and right wing radicalism in Europe. The brutal attacks on asylum seekers, foreigners, and gypsies in Austria and Germany call for adequate measures by the opinion leaders and politicans. Amongst other measures, the educational policies have to be adjusted to oppose racist tendencies of all kinds (cf. Wodak et al., 1990; Van Dijk, 1993). Parts of the argumentative competence which should be taught (more) are: knowledge about the strength and weaknesses of specific schemes of argumentation, the balanced application of these schemes, strategies of verbalization, the ability of critical thinking (cf. Paul, 1987), particularly the critical analysis of prejudiced thought and its inhuman consequences.

\section{Appendix}

\section{A.1. Sources of passages of letters to the editor quoted in Section 2}

(1) Frankfurter Rundschau, 18.10.91; A. Belfellah.

(2) Neue Westfälische, 7.11.91; P. Nipko.

(3) Frankfurter Rundschau, 26.10.91; H. Wagner.

(4) Neue Westfälische, 1./2.11.91; F. Martens.

(5) Frankfurter Rundschau, 10.10.91; K. Beer.

(6) Neue Westfälische, 14.11.91; U. Tünnermann.

(7) Frankfurter Rundschau, 9.10.91; A. Müller.

(8) Neue Westfälische, 19.10.91; G. Arronge.

(9) Haller Kreisblatt, 16.10.91; K.-H. Galling.

(10) Frankfurter Rundschau, 9.10.91; A. Müller.

(11) Neue Westfälische, 19.10.91; L. Brade.

(12) Neue Westfälische, 19.10.91; W. Brockmeyer.

(13) Neue Westfälische, 19.10.91; K.-M. Hartrampf.

(14) Neue Westfälische, 17.10 .91 ; C. Willmann.

(15) Frankfurter Rundschau, q.10.91; A. Müller.

(16) Neue Westfälische, 19.10.91; R. Bruzesse.

(17) Frankfurter Rundschau, 16.10.91; A. Krämer (= L1). 
(18) Profil, 9.12.91; S. Szalachy.

(19) Neue Westfälische, 19.10.91; K.-H. Hartrampf.

(20) Frankfurter Rundschau, 29.10.91; H. Oberst.

(21) Frankfurter Rundschau, 10.10.91; H. Beer.

(22) Spiegel, 19.8.91; G. Bittner.

(23) Frankfurter Rundschau, 26.10.91; H. Wagner.

(24) Neue Westfälische, 19.10.91; Ch. Beyer.

\section{A.2. Full texts and translations of the two letters analyzed in Section 3}

L1: Andreas Krämer, Gießen: Straffällige müssen abgeschoben werden. In: Frankfurter Rundschau, 16.10.91:

So entsetzlich die Vorkommnisse vor dem Ausländerheim in Hoyerswerda sind, so kommen wir nicht umhin, darüber nachzudenken, warum in der nahezu gesamten deutschen Bevölkerung. die Akzeptanz gegenüber Ausländern/Asylbewerbern so gering ist ('Rechtsextremismus verbreitet', $F R$ vom 26.9.).

So ist doch letztlich unbestritten, daß nicht wenig Ausländer mit einer unheimlichen Anspruchsmentalität nach Deutschland kommen und Dinge verlangen, für die Otto Normalverbraucher hart arbeiten muß und die - aus dessen Sicht - über die Rettung des an Leib und Leben bedrohten hinausgehen.

Es ist ferner für die Masse der Bevölkerung einfach unverständlich, warum etwa ausländische Drogendealer, Hütchenspieler, Diebes- und Unterweltbanden nach deren Festnahme umgehend wieder auf freien Fuß gesetzt werden, anstatt sie abzuschieben. Hier liegt wahrlich der Verdacht nahe, daß vieles davon auf das Zauberwort 'Asyl' zurückzuführen ist. So ist es keinesfalls 'rechtsextrem', wenn man fordert, daß Asylbewohner ihr Recht verwirkt haben, wenn sie es dahingehen (sic! M.K.W.K.) mißbrauchen, daß sie in dem Land, das sie aufnimmt und ron dessen Steuergroschen ihr Aufenthalt bezahlt wird, straffällig werden. Dies sollte m.E. nicht so einfach als Stammtischgerede abgetan werden. Jedes Recht kann nur solange durchgesetzt werden, wie es auf die Akzeptanz der Bevölkerung trifft. Wir riskieren andernfalls das kosthare Asylversprechen des $G G$ gänzlich zu verlieren.

So stößt etw'a die multikulturelle Gesellschaft auf wenig Gegenliebe, wenn man sich des Eindrucks nicht erwehren kann, daß die eigene Kultur als letztes kommt. In diesem Zusammenhang sei auch davor gewarnt. Deutschland formell zu einem Einwanderungsland zu machen. Es graut einem schon heute vor den dann zu erwartenden 'Volk ohne Raum'-Theorien. Das verhältnismäßig kleine Deutschland ist eben nicht Kanada oder Australien.

Das Ziel zur Rettung des Artikels 16 GG muß sein, wieder eine breite Akzeptanz in der Bevölkerung zu schaffen. Hierzu bedarf es aber auch der Mitwirkung der Ausländer.

'However terrible the events in front of the asylum-seekers' hostel in Hoyerswerda are; we cannot avoid thinking about the reasons for the low opinion of foreigners/asylum-seekers among almost the entire German population ('Widespread right-wing extremism', FR, 26.9.).

After all, it cannot be denied that a large number of foreigners come to Germany with an unbelievably demanding attitude, asking for things which Mr. Average Consumer has to work hard for and which - in his opinion - go above and beyond rescuing life and limb.

What is more the vast majority of the population cannot understand why foreign drug dealers, gamblers, thieves and gangs are set free immediately after having been arrested instead of being deported. The definite suspicion arises that a lot of this is due to the magic word 'asylum'. It is, therefore, in no way an 'attitude of the extreme right' if one demands that asy- 
lum-seekers lose their rights if they abuse the laws of a country which welcomes them and pays for their upkeep with its taxes. In my opinion this should not simply be dismissed as alehouse politics. A law only can be enforced as long as it is accepted by the population. Otherwise we risk losing completely the precious promise of asylum granted by our constitution.

Thus a multi-cultural society will not find a great deal of support if one cannot avoid the impression that one's own culture is of less importance. In this context I would like to warn against formally turning Germany into an immigration country. I already now shudder at the thought of the 'A people without enough room' theories which will then be heard. The relatively small Germany cannot be compared to Canada or Australia.

In order to save article 16 of the constitution, one needs to create broad foreigner acceptance by the population. However, this will only be possible with the help of the foreigners.'

\section{L2: Uwe Tünnermann, Lemgo: Nur eine kleine Hilfe. In: Neue Westfälische, 24.9.91:}

Die Bundesbürger(innen) haben in diesem Sommer wieder einmal den Eindruck. als stünde Deutschland in der 'Asylantenfrage' vor einem Überlebensproblem. Es vergeht kaum ein Tag, an dem nicht in den Zeitungen ein Artikel ... zum Thema Asylbewerber erscheint....

Die Bundesrepublik Deutschland ist trotz ihrer immensen finanziellen Verpflichtungen nach wie vor ein reicher Industrit'staat. Sie hat nach Angaben von Amnesty International noch nicht einmal ein Prozent der Weltflüchtlingsmenge bei sich aufgenommen; die meisten Asylsuchenden der 'Dritten Welt' fliehen immer noch in angrenzende Entwicklungsländer.

Dennoch wurmt es hierzulande viele, daß diese Menschen aus aller Welt von unserem fleißig erwirtschafteten Bruttosozialprodukt leben. Dabei sollen wir nicht verdrängen, daj.s wir als Industrienation teilhaben an der Ausbeutung der Rohstoffe und Arbeitskräfte der 'Dritten Welt', deren Länder wir durch Schutzzölle. Niedrigpreise, Produktionsdiktate und Kreditbedingungen hindern, sich zu entwicklen (sic! M.K./W.K.). Wir tragen auch üher unsere unsere atlantischen Bündnisverpflichtungen mit dazu bei, daß in Asien. Afrika und Lateinamerika undemokratische Regime aus militärpolitischen Gründen an der Macht bleiben. Wir sind auch als Europäer historisch mit hineinverflochten in die Spätfolgen der früheren abendländischen Kolonia'politik.

Wenn wir Asylsuchende bei uns aufnehmen, leisten wir als Staat eigentlich nur unseren schuldigen Beitrag zur gemeinsamen internationalen Hilfe gegen das Weltflüchtlingselend. Wir sollten deshalb die Asylbewerber nicht ständig unter einen Dankbarkeitsdruck setzen. denn der einzelne Flüchtling kann nichts dafür, daß er im Schatten geboren ist, während wir. im Licht leben. Über die Flüchtling!shilfe geben wir den unterentwickelten Ländern eigentlich nur einen kleinen Teil dessen zurück, was wir ihnen weltwirtschaftlich weggenommen hahen und militärpolitisch heute noch wegnehmen...

'This summer, the citizens of the: Federal Republic are once again under the impression that Germany is facing problems of survival because of the 'asylum-seekers' question. Almost every day articles concerning the issue of the 'asylum-seekers' appear in the newspapers. ...

Despite its immense financial commitments, the Federal Republic is still a rich industrial nation. According to figures published by Amnesty International, it has not even taken up $1 \%$ of all refugees in the world; most asylum-seekers in the Third World still flee into neighboring developing countries.

Nevertheless many people living here are annoyed by the fact that these people from all over the world are living on our gross national product created by our hard work. However, as an industrial nation, we should not forget that we are participating in the exploitation of raw materials and manpower in the Third World, whose development is blocked by our pro- 
tective trade duties, dumping prices, production constraints and credit terms. Moreover, through our NATO commitments we are contributing to the fact that undemocratic regimes can remain in power in Asia, Africa, and Latin America for reasons of military policy. Furthermore, as Europeans we are historically involved in the indirect consequences of the former European colonial Policy.

If we take in asylum-seekers, our country is only providing the contribution which it owes to joint international aid which tries to fight the misery suffered by the world's refugees. Therefore, we should not constantly force the refugees to be grateful because the individual refugee is not responsible for having been born in the darkness while we live in the light. By means of financial aid for the refugees we are only giving back to the underdeveloped countries a small part of what we have taken away from them through the global economy and are still taking away from them through military policy ....'

\section{References}

Apothéloz, Denis, Pierre-Yves Brandt, and Gustavo Quiroz, 1993: The function of negation in argumentation. Journal of Pragmatics 19: 23-38.

Aristotle, 1959. Rhetoric. Ed. by W.D. Ross. Oxford: Oxford University Press.

Aristotle, 1960. Posterior analytics. Ed. and transl. by H. Tredennick. Topica. Ed. and transl. by E.S. Forster. London: Heinemann.

Blair, J. Anthony, 1992. Premissary relevance. Argumentation 6: 203-217.

Cicero, 1951. De oratore. Ed. by A.S. Wilkins. Oxford: Oxford University Press.

Freeley, Austin J.,1986. Argumentation and debate. Belmont: Wadsworth.

Garssen, Bart, 1994. Recognizing argumentation schemes. In: F.H. Van Eemeren and R. Grootendorst, eds., Studies in pragma-dialectics, 105-111. Amsterdam: Sic Sat.

Green-Pedersen, Niels J., 1984. The tradition of the topics in the Middle Ages. München: Philosophia.

Grice, H. Paul, 1975. The logic of conversation. In: P. Cole and J.L. Morgan, eds., Syntax and semantics, 41-58. New York: Academic Press.

Gruber, Helmut. 1993: Political language and textual vagueness. Pragmatics 3: 1-28.

Kienpointner, Manfred, 1992a. Alltagslogik. Stuttgart: Frommann-Holzboog.

Kienpointner, Manfred, 1992b. How to classify arguments. In: F.H. Van Eemeren, R. Grootendorst, J.A. Blair and Ch.A. Willard, eds., Argumentation illuminated, 178-188. Amsterdam: Sic Sat.

Kienpointner, Manfred, 1993. The empirical relevance of Perelman's New Rhetoric. Argumentation 7: 419-437.

Kienpointner, Manffed, 1996. Vernünftig argumentieren. Reinbek: Rowohlt.

Kindt, Walther, 1988. Zur Logik von Alltagsargumentationen. Fachberichte Informatik der EWH Koblenz 3: 1-48.

Kindt, Walther, 1992a. Organisationsformen des Argumentierens in natürlicher Sprache. In: H. Paschen and L. Wigger, eds., Pädagogisches Argumentieren, 95-120. Weinheim: Deutscher Studienverlag.

Kindt, Walther, 1992b. Argumentation und Konfliktaustragung in Äußerungen über den Golfkrieg. Zeitschrift für Sprachwissenschaft 11: 189-215.

Pater, W.A. de, 1965. Les topiques d'Aristote et la dialectique platonicienne. Fribourg: Ed. Saint Paul.

Paul, Richard W., 1987. Critical thinking in the strong sense and the role of argumentation in everyday life. In: F.H. Van Eemeren, R. Grootendorst, J.A. Blair and Ch.A. Willard, eds., Argumentation: Across the lines of disciplines, 379-382. Dordrecht: Foris.

Peirce, Charles S., 1973. Lectures on pragmatism/Vorlesungen über Pragmatismus. Ed. and transl. by E. Walther. Hamburg: Meiner.

Perelman, Chaim and Lucie Olbrechts-Tyteca, 1971. The New Rhetoric. A treatise on argumentation. Notre Dame, IN: University of Notre Dame Press. 
Quintilianus, 1970. Institutio oratoria. Ed. by M. Winterbottom. 2 vols. Oxford. Oxford University Press. Schellens, Peter J., 1985. Redelijke argurnenten. Utrecht: ICG Printing-Dordrecht.

Toulmin, Stephen, 1958. The uses of argument. Cambridge: Cambridge University Press.

Toulmin, Stephen, Richard Rieke and Allan Janik, 1984. An introduction to reasoning. New York: Macmillan.

Van Dijk, Teun A., 1992. Racism and argumentation: Race riot rhetoric tabloid editorials. In: F.H. Van Eemeren, R. Grootendorst, J.A. Blair and Ch.A. Willard, eds., Argumentation illuminated, 243-259. Amsterdam: Sic Sat.

Van Dijk, Teun A., 1993. Elite discourse and racism. Newbury Park, CA: Sage.

Van Dijk, Teun A. and Walter Kintsch, 1983. Strategies of discourse comprehension. New York: Academic Press.

Van Eemeren, Frans H. and Rob Grootendorst, 1984. Speech acts in argumentative discussions. Dordrecht: Foris.

Van Eemeren, Frans H. and Rob Grootendorst, 1992. Argumentation, communication and fallacies. Hillsdale, NJ: Erlbaum.

Van Eemeren, Hans H. and Rob Grootendorst, eds., 1994. Studies in pragma-dialectics. Amsterdam: Sic Sat.

Van Eemeren, Frans H. and Tjark Kruiger, 1987. Identifying argumentation schemes. In: F.H. Van Eemeren, R. Grootendorst, J.A. Blair and Ch.A. Willard, eds., Argumentation. Perspectives and approaches, 70-81.

Van Eemeren, Frans H., Rob Grootendorst, Sally Jackson and Scott Jacobs, 1993. Reconstructing argumentative discourse. Tuscaloosa, AL: University of Alabama Press.

Walton, Douglas, 1991. Bias, critical doubt, and fallacies. Argumentation and Advocacy 28: 1-22.

Walton, Douglas, 1992. The place of emotion in argument. University Park, PA: Pennsylvania State University Press.

Warnick, Barbara, and Susan L. Kline, 1992. The New Rhetoric's argument schemes: A rhetorical view of practical reasoning. Argumentation and Advocacy 29: 1-15.

Woods, John and Douglas Walton, 1989. Fallacies: Selected papers 1972-1987. Berlin: Foris/De Gruyter.

Wodak, Ruth et al., 1990. 'Wir sind alle unschuldige Täter'. Diskurshistorische Studien zum Nachkriegsantisemitismus. Frankfurt i. M.: Suhrkamp. 